\title{
Thoughts on the Construction of China's Education Informationization Infrastructure
}

\author{
Lijun Duan \\ School of Computer, Hubei University of Education, No. 129, Gaoxin Second Road, Wuhan 430205, China \\ Email: duanlijun@hue.edu.cn
}

\begin{abstract}
To improve education informatization level in China, this paper focuses on the construction of education informatization infrastructure. After analyzing the status of education informatization infrastructure in education informatization process and the connotation of education informatization infrastructure, this paper discusses how to build education informatization infrastructure from the aspects of construction planning, construction content, supporting resources and application level, and also gives countermeasures.
\end{abstract}

Keywords: Education informationization; infrastructure; construction; thoughts

\section{Introduction}

In recent years, the information wave represented by technologies such as "Internet + " and artificial intelligence has profoundly affected and changed all aspects of China's social and economic life. Education in the informatization background is undergoing profound changes, presenting the development trend of education resource digitization, teaching support network and learning mode diversification, bringing unprecedented opportunities and challenges to education teaching, calling for education concept update and teaching behavior change [1].As an important position for talent cultivation and subject construction, colleges and universities should actively adapt to the development of modern information technology, actively adopt key technologies to carry out the innovation of education teaching method, and strive to improve education teaching effect. Therefore, how to effectively carry out the construction of teaching informatization has become one of the problems that must be solved in the construction of modern colleges and universities. Education informatization infrastructure is the prerequisite for education informatization. This paper discusses and considers the status of education informatization infrastructure in education informatization process, the connotation of education informatization infrastructure and how to build education informatization infrastructure.

\section{Status and Connotation of Education Informatization Infrastructure}

At present, there is no unified definition of education information concept at home and abroad. Terms like "ICT for Education" and "Educational ICT" are commonly used abroad to highlight the essence of Education informatization, that is, Education informatization is the application of Information and Communication Technology (ICT) in Education process. The main views on education informatization in China include: education informatization is the process of "using modern IT in education, developing education resources and optimizing education process to cultivate and improve students' information literacy and promote education modernization" [2]. In [3], the word "education informatization" is defined as "in the field of education wide application of modern IT, further development and utilization of information resources, make IT interact with education activity and the process of integration, in order to promote the reform, development and innovation of education and accelerate the process of modernization of education, make education conforms to the requirement of information society, eventually forming a based on the modern IT, basic elements and information become the education activity of new education form -- informatization education.". In [4], "education informatization" is interpreted as "the universal application and promotion of information and information technology in education, teaching field and education, teaching department". Some researchers believed that "the so-called education informatization is a process of systematically improving and transforming education using information and communication 
technology [5]. Although these definitions are different, they all point out the connotation features of education informatization, that is, education informatization is a dynamic process driven by ICT.

Discussion on the elements of education informatization process has never stopped, and some researches have put forward their own views. Jiao J. et al. proposed that the elements of education informatization mainly include policy, infrastructure, software resources, human resources, informatization management, education informatization evaluation, teaching and learning reform, learning reform and other eight parts [5]. According to Wu D., infrastructure, digital education resources, management informatization, teaching and learning application and guarantee mechanism are the five core elements of education informatization development [6]. Xie Y. et al. regard organizational management, environmental construction and application, resource construction and application, team construction, information technology application and innovation development as important indicators of education informatization evaluation [7]. Gu X. classified infrastructure, informatization resources, teachers, education informatization application, education informatization rules and regulations, and education informatization industry as the six connotations of education informatization [8].

Education informatization infrastructure contains a variety of contents. At present, there is no unified standard definition. 2017 National Education Technology Plan Update issued by the technical office of Education of the U.S. department of Education [9] divides the infrastructure of education informatization into four categories: Ubiquitous connectivity, Powerful learning devices, high-quality digital learning, and Responsible use policies. The domestic views are basically similar, for example, Liu X. et al. proposed that the infrastructure construction mainly consists of vital energy ratio, man-machine ratio, network coverage rate, network equipment, multimedia classroom configuration, digital satellite transmission system and network structure [10]. Cao Q. et al. divided the construction of basic informatization infrastructure into three categories: informatization teaching environment, network facilities and terminal equipment [11].

Based on the above, this paper believes that from the perspective of informatization business process, the elements of education informatization mainly consist of five parts: infrastructure, platform system, teaching resources, role group and guarantee system. Among them, the infrastructure is the physical education information system, and provide physical support for the whole system, it is the prerequisite of education informatization, determines the degree of education informatization development space and extensible, mainly includes the information network, information classrooms and laboratories, servers and computers, mobile terminals, etc., its constituent structure as shown in figure 1.

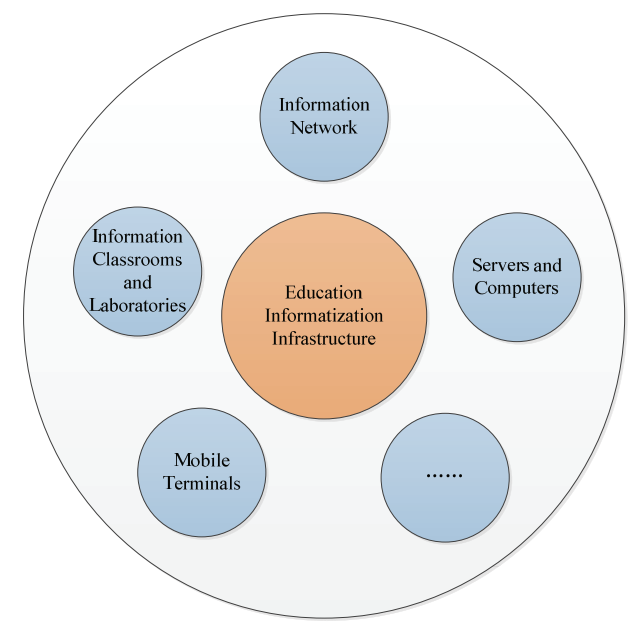

Figure 1. Constituent Structure of Education Informatization Infrastructure

\section{Measures for Education Informatization Infrastructure Construction}

As mentioned above, education information infrastructure mainly consists of information network, information classroom and laboratory, servers and computers, and mobile terminals. It should be pointed out that the information network is divided into two levels, namely backbone network and campus Intranet. The former is mainly determined by the construction level of education information 
infrastructure in a country, while the latter depends on the informatization construction intensity of universities themselves. This section mainly discusses how to carry out education informatization infrastructure construction.

\subsection{Forward Planning}

With the rapid development of modern information technology, the technology update cycle is short and the difference is large, which requires that the infrastructure construction planning of education informatization should be forward-looking and take into account the expandability of existing infrastructure. There are a lot of successful experience in this field abroad, South Korea emphasized in education information infrastructure construction organization and management and division of labor cooperation, pay attention to the top-level design and macro planning, special measures are taken to protect the capital investment and persistent, to continuously adapt to technology development and the trend of change, make the informatization infrastructure construction level is a world leader [12].At the national and provincial levels, Canada promotes the continuous development of education information infrastructure construction through a number of informatization strategies, such as Pan-Canada advanced scientific research projects, information highway projects and knowledge infrastructure projects [13].Therefore, in the construction of backbone network, the country needs to be forward-looking planning; in the construction of campus network, schools need to consider the issue of sustainable development.

\subsection{Building Contents in Various Forms}

Education informatization infrastructure construction should first adhere to the principle of diversity. In the past two decades, great progress has been made in China's network infrastructure and broadband network construction, with the household bandwidth doubling and the construction of a special backbone network -- China Education and the Scientific Research Computer Network (CERNET). This has provided a solid foundation for education informatization construction in universities. But for university education informationization connotation construction, only a dedicated backbone or not enough, also need to be extensively and quickly laid the wireless campus network, the construction of a high standard of information classrooms and laboratories, the configuration is higher than and machine than computers and mobile terminals, offers a variety of access to information means and way for the teachers and students, which can realize the teacher/student is convenient, flexible and quick deployment/access to learning resources.

\subsection{Matching Corresponding Digital Resources}

After the hardware facilities in education informatization infrastructure are completed, we should pay attention to the application of education resources in education. Next, the teacher database, education software and teaching platform should be built to provide abundant and high-quality digital resources to assist students in classroom learning. This integration of digital resources and courses can provide students with learning tools and improve resource utilization, thus saving education costs. And, along with the Internet of things, big data and cloud computing, the popularization of information technology, the seamless integration of education resources, extensive study in learning environment, based on large data analysis and so on are creatively changes the traditional education method and organizational form, change the traditional teaching goal, teaching concept, teaching organization form, promote the informationization teaching extend from traditional education to modern education. Therefore, how to effectively use education information infrastructure to build an efficient information teaching environment anytime and anywhere is also one of the issues we must consider.

\subsection{Improving the Application Level}

The low utilization rate of education information infrastructure is a bottleneck of education information infrastructure development in China. After decades of development, although education information infrastructure construction in China has made remarkable achievements, there are still problems of paying attention to the construction of hardware facilities and ignoring the application of education. This 
phenomenon leads to low input and output ratio of education information infrastructure in China and low benefit. To solve this problem, on the one hand can take advantage of the cloud platform virtualization technologies such as education, aggregation and integration of software and hardware resources, weakening the hardware, software, data, network, storage and other IT system physical dependence between different level of resources, to achieve intensive and transparent management and realize the dynamic allocation and according to the need to use, so as to improve the elasticity of computing resources and flexible restructuring. On the other hand, a variety of resource sharing and education teaching application modes can be promoted to improve teaching quality and promote the balanced development of education through information technology.

\section{Conclusion}

The construction of education informatization infrastructure plays a fundamental and leading role in the development of education informatization, creating necessary conditions for the practice of informatization in education. In the process of education informatization infrastructure construction in China, we should draw on the advanced experience of foreign countries and combine the features of China's higher education to plan systematically and take effective measures to effectively improve education informatization infrastructure construction level. The research work in this paper provides reference for the construction of education informatization infrastructure in China. In the subsequent research work, we will continue to further study, further clarify and plan measures, and improve the feasibility of the plan.

Acknowledgments: This work is supported by Provincial Teaching Research Project of Hubei Province, China under Grant No. 2017397.

\section{References}

1. Kang S. On Transformation of instructional modes under the background of informationization, Educational Research, 2015(06): 96-102.

2. Nan G. Several theoretical and practical problems of education informatization construction (part 1), E-education Research, 2002(11): 3-6.

3. Le J. Analysis of education informationization essence, E-education Research, 2006(09):16-19.

4. He K. New development of education informatization theory in China, China Educational Technology, 2011(01):1-19.

5. Jiao J., Jia Y. and Ren G. Research on macro policies and strategies of educational informatization, Journal of Distance Education, 2014(01):25-32.

6. Wu D., Yu X., Lu C. and Shi Y. Research on the indicator system of the development of education informatization, Open Education Research, 2014, 20(01):92-99.

7. Xie Y. and Chang Y. The construction of a performance-oriented educational informatization evaluation model, China Educational Technology, 2015(01):56-61+92.

8. Gu X. and Guo R. Retrospect and prospect of educational informationization: research on localized evolution, E-education Research, 2014(01):25-32.

9. Reimagining the Role of Technology in Education: 2017 National Education Technology Plan Update. [DB/OL].[2018-10-18]. https://tech.ed.gov/files/2017/01/NETP17.pdf

10.Liu X., Wang Y., Wang X., Ren G. and Jiao J. Research on the development strategy of ICT infrastructure in education in the process of educational informatization, Journal of Distance Education, 2014,32(05):24-33.

11. Cao Q., Yu X. and Rao J. Research on the foreign development policy and maintenance mode of ICT infrastructure in education, China Educational Technology, 2016(04):14-20.

12.Wu D., Yu X. and Zhu S. A Study of the ICT infrastructure in education of South Korea. Modern Distance Education Research, 2014(05):86-94.

13.Zhang C. Overview of education informatization development in Alberta, Canada. The Chinese Journal of ICT in Education, 2015(21):7-11+79. 